\title{
Flood Hazard Mapping in Rural Area: Case of Ephemeral Watercourses in SidiBoulenouar Zone
}

\author{
Imane Amar ${ }^{1, *}$, Said Bengamra ${ }^{1}$, Najat Amarjouf ${ }^{2}$, and Abdellah Azougay ${ }^{1}$ \\ ${ }^{1}$ Applied Geosciences Laboratory "LGA", Department of Geology, Faculty of Sciences Oujda - FSO, Mohammed Premier University, \\ Oujda. \\ ${ }^{2}$ Research and Development in Engineering Sciences Laboratory "LRDSI", Department of Earth and Environmental Sciences, Faculty \\ of Science and Technology Al Hoceima - FSTH, Abdelmalek Essaadi University.
}

\begin{abstract}
The eastern region of Morocco is characterized by an arid to semi-arid climate. It is often confronted with heavy rainfall episodes that can generate floods that can cause adverse human and property damage. This work studies hydrological risk in the SidiBoulenouar area (Oujda province) to model floods and map risk areas. The method used is to determine the watersheds and their watercourses, then to calculate the flows with the mathematical formulas. Topographic data were extracted from a $12.5-\mathrm{m}$ resolution DEM derived from the ASTER (Advanced Spaceborne Thermal Emission and Reflection Radiometer). GDEM (Global DEM). The DEM was used to delimit the hydrographic network with ArcMap software. The use of HEC RAS 1D was necessary to delimit the flooding area. The results of the 1D hydraulic modeling of the centennial flood showed that four ephemeral watercourses landlock the rural area of SidiBoulenouar at the time of the floods.
\end{abstract}

\section{Introduction}

Water is becoming increasingly important in our lives. However, it requires rational management to control its scarcity, but also its excess. This management is essential to ensure the supply of drinking and industrial water, agricultural needs, energy production, and the maintenance of the quality of our environment. This management requires the development of adequate methods and tools to minimize flood risks [1]. In terms of natural disasters worldwide, floods are the leading cause of natural disasters, claiming around 20,000 victims yearly [2]. The hydrological risks in Eastern Morocco are caused by severe floods resulting from heavy rainfall over a limited area in a short period. These precipitations are, in most cases, sudden and have a relatively high peak flow. [3].

The area of SidiBoulenouar situated in Oujda Province is drained by the two watercourses: Hassa creek and Abidine creek. These two creeks are temporary and generally flow during rainfall. They provoke floods at each thunderstorm, which disrupts the activities of the local population. The objectives of this work are flood modeling and spatial mapping of flooded areas in the center of SidiBoulenouar and its immediate neighbors by using the HEC RAS $1 \mathrm{~d}$ model. This study was based on identifying the hydrological characteristics of the watersheds, calculating concentration times and peak flows for different return periods, the simulation of floods to determine the areas at high risk of flooding, and consequently, the proposal of floods civil engineering developments.

\section{Geographical and Geological context of the Study Area}

The centre of SidiBoulenouar is constituted by the douars of Oulad Ali Ben Yahya, Oulad Ben Gana, OuladBouhasaka and the seguia of the Guernaz stream which are part of the rural commune of SidiBoulenouar. This rural commune is bounded to the north and east by the rural commune of SidiMoussaLamhaya, west by the rural commune of Mestferki, and to the south by the province of Jerada. The commune is administratively attached to the Caïdat of Isly. The villages are located southwest of Oujda, about $20 \mathrm{~km}$ as the crow flies and accessible from Road N 17 and then by a track crossing the Isly stream. The study area is located in the OujdaTaourirt corridor (eastern Morocco), bordered to the north and south, respectively, by the BeniSnassen belt and the Oujda mountains. This sector covers an area of about $900 \mathrm{~km}^{2}$. From a geological point of view, the western mountain ranges of BeniSnassen and the mountains of Oujda are made up of a Paleozoic basement (schist and granite) surmounted by the Triassic volcano-sedimentary complex [4], which is covered by Jurassic carbonate formations. The Naima-El Aioun corridor is a plain corresponding to a large subsidence basin in which sediments of tertiary and quaternary age [5].

\footnotetext{
* Corresponding author: amar.imane@ump.ac.ma
} 


\section{Materials and Methods}

We started with a hydrological study based on calculating the physical parameters (Perimeter, Area, Length, and Width of the Equivalent Rectangle, Length of the main watercourse, Gradient) of the different watersheds and watercourses crossing the study site. For this purpose, we processed the 30-meter resolution, digital terrain model using ArcGIS. Calculating the time of water concentrations in a watershed is defined as the maximum amount of time it takes for a drop of water to travel the hydrological path between a point in the watershed and the watershed outlet. The time of concentration is estimated using the most widespread formulas in Morocco (Formulas of Turazza,

Ventura, Kripich, D. Californian, H. Giandotti, Passini) [6] in addition to US Corps and Spanish. Then the statistical processing of rainfall data, peak flows for different return periods with different methods in the literature such as empirical formulas that consider two essential factors the size of the watershed and topographic Gradient.

The Gradex method is widely used for estimating project debit from rainfall data because, in most cases, the flow samples are much less extensive than rainfall samples. This means that it will be challenging to extrapolate return times of 10 or 20 years based on the flow sample. On the contrary, as rainfall samples are generally longer, it will be easier to determine the centennial value accurately. The fronco-Rodier method is an estimate of flows by analogy with other similar and adjacent watersheds. The criteria for similarity are essentially the morphology and rainfall regime.

The Hec-RAS established the flood simulation. Software developed at the Hydrologic Engineering Center of the US Army Corps of Engineers [7]. Calculations of water lines of gradually varying flows are based on Bernoulli's equation. The ManningStrickler equation evaluates load losses for the friction term and by contraction-expansion coefficients. In abruptly varied flows, HEC-RAS uses the quantity of movement equation [7-8].

Finally, a hydrological study was carried out to determine flood debits using various empirical methods. These flows will be used in the hydraulic modeling carried out by the HEC-RAS software to simulate the flow of the studied rivers and delimit inundable zones.

\section{Results and Discussion}

\subsection{Physical parameters of watersheds}

The morphometric parameters of the different watersheds of SidiBoulenouar are summarized in Table 1. The four watersheds are high-altitude basins with limited surfaces and elongated shapes.

These characteristics were used in the calculation of concentration-time later.
Table 1. Physical characteristics of the four watersheds of SidiBoulenouar.

\begin{tabular}{|c|c|c|c|c|c|c|}
\hline & Units & Symbol & $\begin{array}{c}\text { Basin } \\
\text { Hassa }\end{array}$ & $\begin{array}{c}\text { Basin } \\
\text { Abidine }\end{array}$ & $\begin{array}{c}\text { Basin } \\
\text { Rivelet } \\
\mathbf{1}\end{array}$ & $\begin{array}{c}\text { Basin } \\
\text { Rivelet } \\
\mathbf{2}\end{array}$ \\
\hline Surface & $\mathrm{Km}^{2}$ & $\mathrm{~S}$ & 2.20 & 1.41 & 0.14 & 0.05 \\
\hline Perimeter & $\mathrm{Km}$ & $\mathrm{P}$ & 8.75 & 5.11 & 1.76 & 0.96 \\
\hline $\begin{array}{c}\text { Compactness } \\
\text { index }\end{array}$ & $\mathrm{KG}$ & 1.65 & 1.20 & 1.32 & 1.22 \\
\hline $\begin{array}{c}\text { Length of } \\
\text { watercourse }\end{array}$ & $\mathrm{Km}$ & $\mathrm{Leau}$ & 3.02 & 0.43 & 0.55 & 0.03 \\
\hline $\begin{array}{c}\text { Equivalent } \\
\text { rectangle } \\
\text { length }\end{array}$ & $\mathrm{Km}$ & $\mathrm{L}$ & 4.02 & 1.55 & 1.20 & 0.76 \\
\hline $\begin{array}{c}\text { Equivalent } \\
\text { rectangle } \\
\text { width }\end{array}$ & $\mathrm{Km}$ & 1 & 1.10 & 0.92 & 0.85 & 0.42 \\
\hline $\begin{array}{c}\text { Maximum } \\
\text { Altitude }\end{array}$ & $\mathrm{M}$ & $\mathrm{Hmax}$ & 1195 & 960 & 796 & 772 \\
\hline $\begin{array}{c}\text { Minimum } \\
\text { altitude }\end{array}$ & $\mathrm{M}$ & $\mathrm{Hmin}$ & 744 & 741 & 749 & 744 \\
\hline $\begin{array}{c}\text { Height } \\
\text { difference }\end{array}$ & $\mathrm{M}$ & $\mathrm{Dth}$ & 451 & 219 & 47 & 28 \\
\hline $\begin{array}{c}\text { Averageslope } \\
\text { Mand }\end{array}$ & $\%$ & $\mathrm{Imoyenne}$ & 14.9 & 51.22 & 8.52 & 90.88 \\
\hline
\end{tabular}

\subsection{Estimation of concentration time Based}

On the physical characteristics of the watersheds, we calculated the concentration-time by the different methods, which were then used to estimate the point flow (Table 2).

Table 2. The concentration time calculated by the various empirical methods in (h)

\begin{tabular}{|c|c|c|c|c|}
\hline Formulas & $\begin{array}{c}\text { Hassa } \\
\text { Creek }\end{array}$ & $\begin{array}{c}\text { Abidine } \\
\text { Creek }\end{array}$ & Rivelet1 & Rivelet2 \\
\hline Giandotti & 0.62 & 0.46 & 0.42 & 0.22 \\
\hline Turrazza\&Passini & 0.53 & 0.13 & 0.16 & 0.01 \\
\hline Ventura & 0.49 & 0.21 & 0.16 & 0.03 \\
\hline Kirpich & 19.36 & 2.67 & 6.49 & 0.28 \\
\hline Espagnole & 2.30 & 1.20 & 0.74 & 0.30 \\
\hline Van Te Chow & 0.46 & 0.09 & 0.18 & 0.01 \\
\hline Californienne & 0.71 & 0.10 & 0.24 & 0.01 \\
\hline US Corps & 0.94 & 0.16 & 0.28 & 0.02 \\
\hline Chosen value & 0.65 & 0.40 & 0.17 & 0.01 \\
\hline
\end{tabular}

\subsection{Simulation of flood flow in the area of SidiBoulenouar}

Using HEC-RAS, the modeling of the flows generated bythe rivers gave the following results for the different return periods of 10, 20, 50, and 100 years (Fig. 1, 2, 3, and 4). 


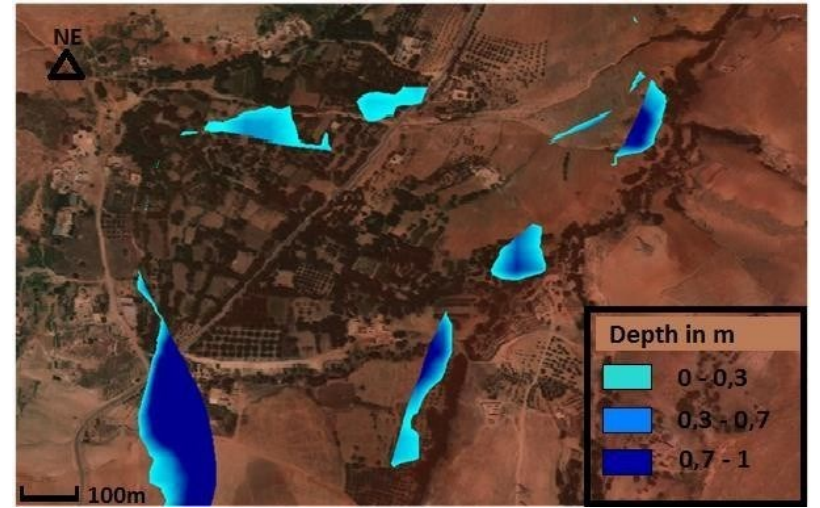

Fig. 1. Result of flood simulation in the study area for a 10year return period

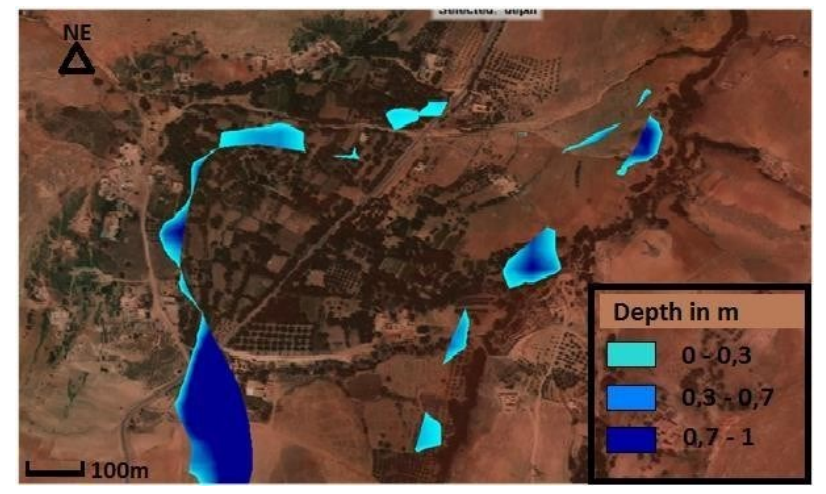

Fig. 2. Result of flood simulation in the study area for a 20year return period

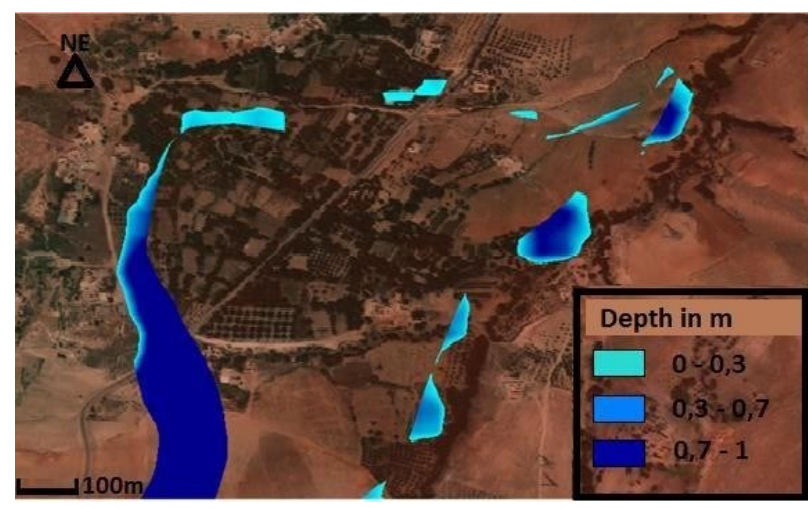

Fig. 3. Result of flood simulation in the study area for a 50year return period

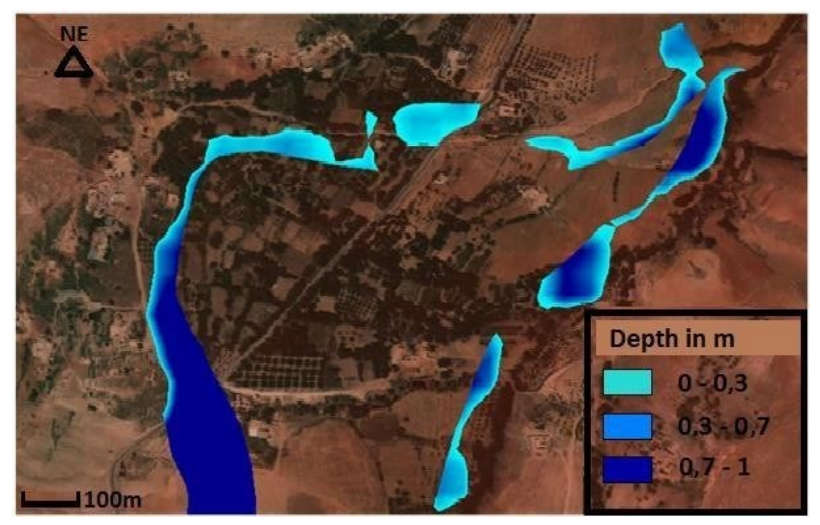

Fig.4. Result of flood simulation in the study area for a 100year return period.
The overflows affect the intersection of the watercourses with the railroad tracks, farmland, and RP6030, which is not developed by any hydraulic structure. Flooding can also threaten the lives and property of the adjacent population. Therefore, three variants of hydraulic development have been proposed. (1) The diversion from Abidinecreek to Hassacreek upstream through a trapezoidal channel with a 5\% slope and another channel downstream. (2) The second variant consists of sinking the buzzards on either side of the existing scuppers, and (3) the final solution is the construction of retention basins (Table 3 ).

\section{- Variant 1}

Table 3. The geometry of the trapezoidal channels according to the materials used.

\begin{tabular}{|c|c|c|c|}
\cline { 3 - 4 } \multicolumn{2}{c|}{} & Canal 1 & Canal 2 \\
\hline \multirow{2}{*}{ Channel 1 } & With the soil & 1.5 & 2 \\
\cline { 2 - 4 } & With concrete & 2.5 & 1.5 \\
\hline \multirow{2}{*}{ Channel 2 } & With the soil & 1.6 & 3 \\
\cline { 2 - 4 } & With concrete & 1.5 & 2.3 \\
\hline
\end{tabular}

The slope of the rivers crossing the center of SidiBoulenoir is steep, averaging 5\%, which will increase the speed of the flows and aggravate scouring, especially during the diversion of Abidinecreek towards Hassa creek. The insertion of para-digs to fight against scouring and, at the same time, waterproofing is necessaryin this case study.

\section{- Variant 2}

We kept the dimensions of the existing scupper without any variation, only the execution of the cleaning to emptyit, and we used the method of horizontal hydraulic jacking in order to insert the buzzard with a diameter of about $1000 \mathrm{~mm}$ so as not to modify the shape of the railway track, and we played only on their number to avoid any possible overflow

\section{- Variant 3}

A water retention basin is a storage area for rainwater, either underground or open-air. They are intended to temporarily store water to prevent flooding downstream in the watershed for the slow release of water.

A buffer zone can help manage fluctuations in rainwater input from these surfaces to release homogeneously into the environment.

\section{Conclusion}

Hydrological risk modeling in the SidiBoulenouar area is a methodical work that consists of following a welldefined methodology. It starts by identifying the characteristic information that emerges from the Hassacreek basin and the largest in terms of surface area $2.20 \mathrm{~km}^{2}$, followed by a hydrological study to describe the rain-flow transfer within the basins concerned and whose output

corresponds to the specific flows for each return period such as $\mathrm{T}=10$ years, $\mathrm{T}=20, \mathrm{~T}=50, \mathrm{~T}=100$. These 
specific flows were used in a hydraulic study to describe the propagation of floods in SidiBoulenouar.

\section{Acknowledgment}

Special thanks go to Ryme EL AZZOUZ for his help. The authors would also like to extend their sincerest gratitude tothe anonymous reviewers for their thoughtful comments and suggestions for improving this manuscript.

\section{References}

1. S. Riad, 2003, "Typologie et analyse hydrologique des eaux superficielles à partir de quelques bassins versants représentatifs du Maroc," Thèse de Doctorat en cotutelle, Univ. Sciences et Techniques de Lille \&Univ. IbnouZohr d'Agadir. 154 pages.

2. N. Simona Et L. Cedric, 2007. Gestion durable des zones inondables dans le Delta du Danube (Roumanie). 1res Journées Scientifiques InterRéseaux de l'AUF, Gestion Intégrée des Eaux et des Sols. Ressources, Aménagements et Risques en Milieux Ruraux et Urbains, Hanoi, Vietnam, 10 p.

3. N. Amarjouf, 2018. "Interactions entre cruesruissellements et aménagements de territoire et leurs impacts sur les versants Nord de la péninsule de Guelâaya: Cas de la baie de Melilla Béni Ansar et la baie de Betoya." (Maroc Nord Oriental).Thèse de Doctorat, Faculté des sciences, Université Mohamed Premier, Oujda. 302 pages.

4. N. Rifai, A. Khattabi, And L. Rhazi, 2014, "Modelisation des crues des rivières pour la gestion intégrée du risque d'inondation: Cas du bassin versant de Tahaddart (Nord-ouest du Maroc)," Rev. des Sci. l'Eau. 27pages, pp. 57-69.

5. S. Bengamra And M. Oujidi, 2015 "Mineralogy of atmospheric dust deposits in the Naima-El Aiounbasin (Eastern Morocco)," pp. 2076-2082.

6. N. Amarjouf. M. Oujidi. D. Meijer. W. Klop. 2019. ISHHydrauliqueEngeneering journal. Evaluating ephemeral watercourse discharges by hydrologichydraulic modelling: application to the Kert River basin, Morocco. pp 1-11.

7. USACE., 2016. HEC-RAS Hydraulic Reference Manual. Version 5.0.3.

8. M. Lahsaini And H. Tabyaoui, 2018, "ModelisationHydraulique Mono Dimensionnel Par HEC RAS, Application Sur L'oued Aggay (Ville De Sefrou)," Eur. Sci. Journal, ESJ. 18, p. 110. 